\title{
風の道と都市気候形成 Ventilation Path and Urban Climate
}

成田健一*

Ken-ichi NARITA

\section{1. はじめに}

ヒートアイランド対策大綱では、対策の一つの柱と して「都市形態の改善」を挙げており、その目標とし て「...緑地の保全を図りつつ、緑地や水面からの風の 通り道を確保する等の観点から水と緑のネットワーク の形成を促進する」と嵒っている。このように、一般 には連続したオープンスペースを対象に「風の道」と いう言葉が用いられることが多いが、ここでは、都市 の通風や換気を含めた「風通しの良い」街づくりとい う観点から、風の道」と都市気候の関連について述べ ることとする。

もともと「風の道」という言葉は、シュトッツガル トに代表されるように、内陸の盆地状の都市において、 大気污染対策として周辺の緩斜面から夜間の冷気流を 市街地中心部まで誘導するという意図で使われたもの である（図 1)。それに対し、わが国の場合は暑熱対策

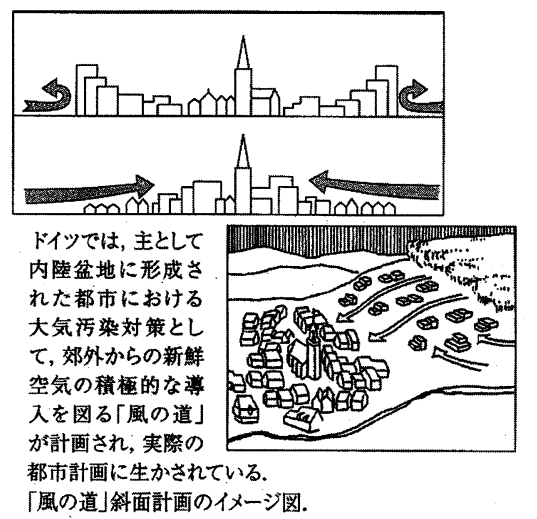

図 1. ドイツの風の道のイメージ
として海風を中心とした日中に吹く風を対象にしてい る場合が多い。従って、ヒートアイランド対策という 目的も、対象としている現象自体も、御本家のドイツ とは異なることに留意する必要がある。一方、ヒート アイランド対策の中でも、熱帯夜の対策として夜間の 山風や大規模緑地からの冷気流が有効であるという指 摘も近年なされていることから、本稿ではそれらにつ いても触れることとする。ただし、現象のスケールや メカニズムが異なることから、ここでは両者を分けて 各々別々に議論を進める。

\section{2. 風通しと街路の温熱環境}

ヒートアイランド対策として、「風通し」が重要で あることを確認する意味で、まず街路空間における微 気候実測の一例を紹介寸る 1)。図 2 は、広島市の東西 街路の歩道橋を利用して夏季日中に観測された、10 分 間の気流と気温の変化である。この間、上空の南から の海風が、前半は徐々に弱まり、ほぼ無風になった後、 5 分半頃から再び強くなるという変化を示している。 この間、上空の風が吹き降ろす街路北側の各観測点 （T7〜T9）では、わずか 10 分の短い時間に約 $4{ }^{\circ} \mathrm{C} に$ 及ぶ非常に大きな気温の変化が起こっている。海風が 止んだ時間帯の気温は $37^{\circ} \mathrm{C}$ 超えており、それが海風 の吹き降ろしの再開により一気に $33^{\circ} \mathrm{C}$ 程度まで低下 している。この例から、街路空間の温熱環境は、風通 しの有無によって大きく左右されていることがわかる。 夏季の街路空間は、高温化する舗装面からの顕熱と車 からの排熱が相まって、劣悪な熱環境となる。風通し

* 日本工業大学工学部建築学科 教授

Professor, Department of Architecture, Nippon Institute of Technology 


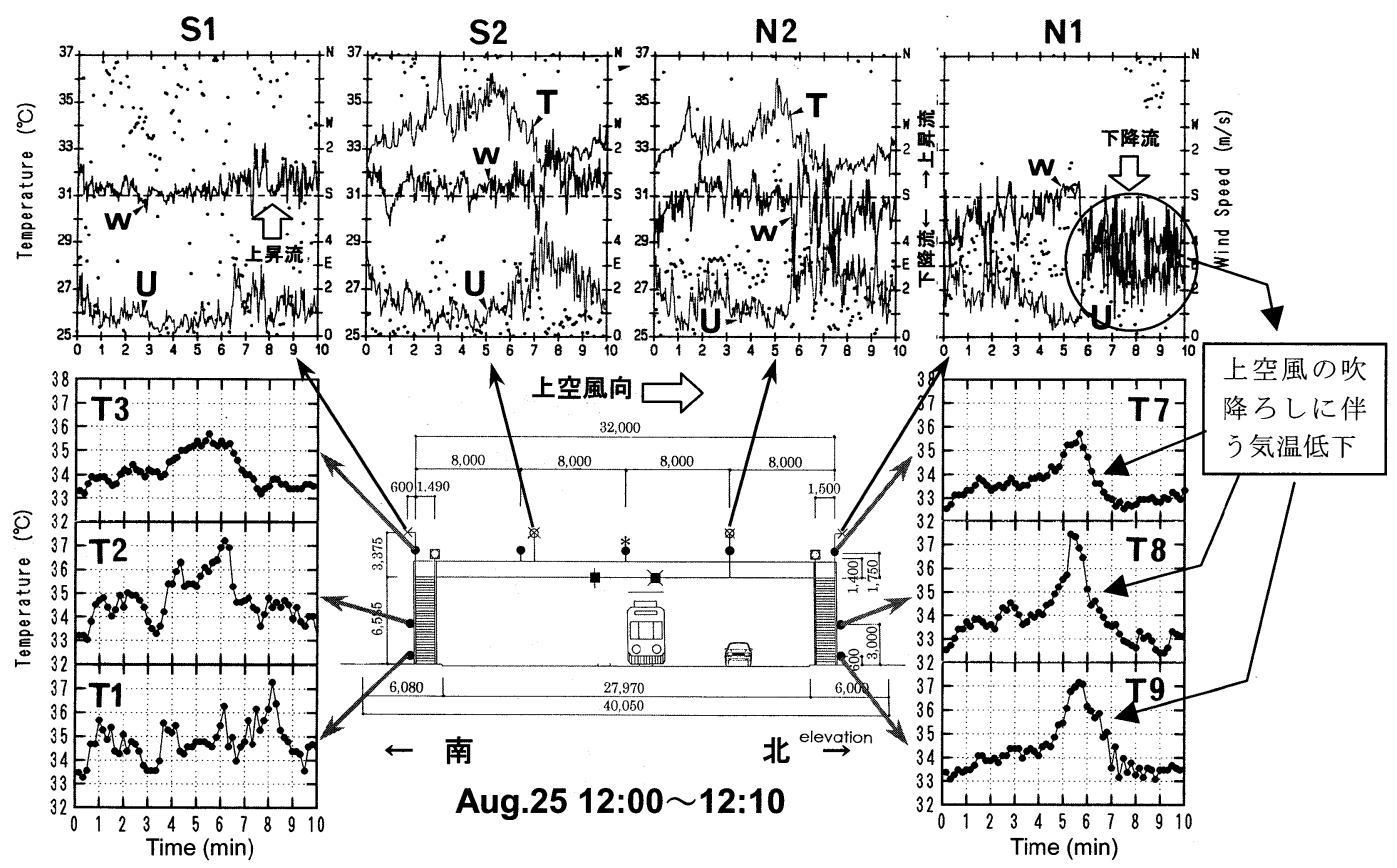

図2. 歩道橋を利用した東西街路における気流と温熱環境の実測例

（T1 9; 熱電対、S1,S2,N2,N1;超音波風速温度計[T:気温, U:合成風速, w:鉛直成分風速 $])$

市街地平均気温

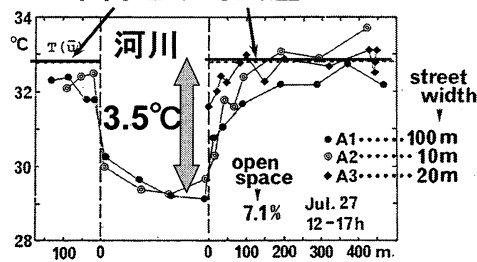

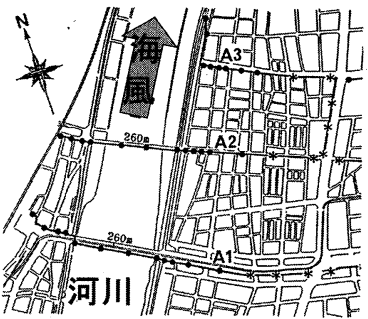

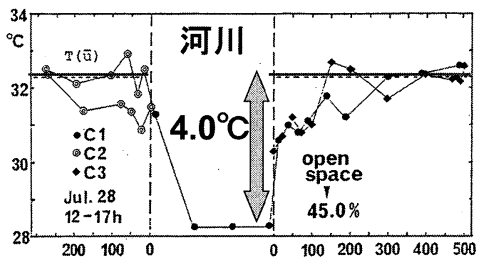

図3. 河川周辺の気温分布(広島市太田川の事例)(3)

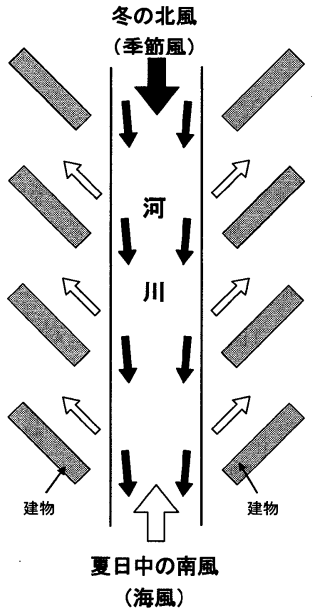

図5. 河川沿いの建物配置のエ夫によ る河風の選択的導入のイメージ(5)
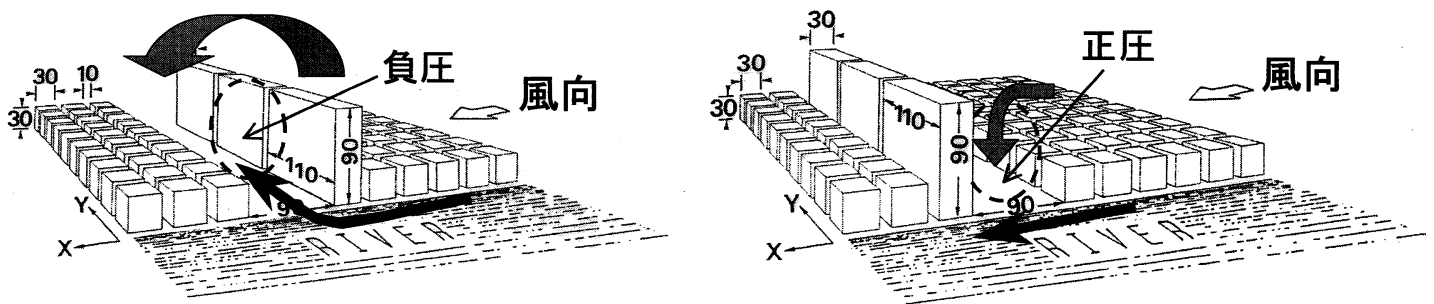

図4. 河川周辺の建物配置による河風の広がりの違い(風洞実験)一左: 街路の風上側を高層化、右:街路の風下側を高層化 (4) 
の悪い街路では、これらの熱が拡散されず、歩行者空 間に滞留することになる。風通しの必要性は、一目睹 然である。

\section{3. 河川を利用した風の道}

河川がヒートアイランドを分断するのではという指 摘は地理学分野で古くからなされており、すでに 1979 年に広島市を対象にラフではあるが、その様子が気温 分布図として表されている ${ }^{3)}$ 。広島ではその後、村川 ら 4)による詳細な実測が行われ、風の道のデザインに つながる多くの知見が示されている。図3は、河川に 直交する街路に沿った気温分布の実測結果で、夏季日 中、河川上では $3.5 \sim 4.0^{\circ} \mathrm{C}$ 周辺市街地よりも低温とな っている（河口からの距離は $2.5 \sim 4.5 \mathrm{k} \mathrm{m}$ ）。河道と いう空間は、市街地に比べ粗度も小さいく、人工排熱 もない。この時期、河川水は気温より冷たい。従って、 河川上で風速が強く気温が低くなるのは当然である。 結果として、河川が貫流する都市では、本来ならば一 つのドーム状に形成されるヒートアイランドが、河道 で分断される形となる。

海風が海域から市街地に侵入すると、市街地という 地表面境界条件に対応した内部境界層が下層に形成さ

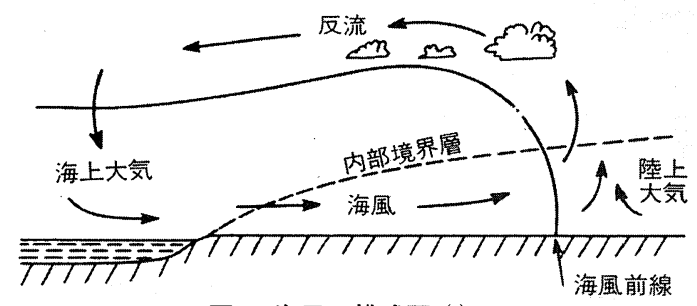

図6.海風の模式図 ${ }^{(6)}$
れる（図 6)。一般に、内部境界層の厚さは、吹走距 離（フェッチ：ここでは海岸線からの距離）の 1/10〜 1/100 程度の割合で発達する。すなわち、地表付近に は高温で風速の弱い気層が形成され、徐々にその厚さ を増していく。従って、海岸からある程度内陸に入っ た市街地においては、少なくとも地表近くの高さでは 直接海風の恩恵を得ることはできなくなる。

河風が、ヒートアイランド対策として注目される理 由は、地表近くのレベルにおいて、市街地の奥深くま で海風を変質させずに導くという点にある。そして、 この河風をヒートアイランド対策として生かすには、 周辺市街地へとさらに導く工夫が必要となる。図 3 の 実測結果をみても、街路幅や建物密度によって、河風 の横方向への広がりに差があることがわかる

図4は、風洞実験において、このような河風の広が りと周辺建物配置との関係を検討した結果の一例であ る5)。河川に直交する街路において、街路の風下側を 高層化するか風上側を高層化するかで、街路空間への 河風の広がりが大きく異なってくる。これは、高層建 物の背後は負圧域となり河風を誘引するのに対し、建 物風上側は壁面に沿った吹き降ろし気流により正圧域 となり河風の侵入を妨げるためである。同様の検討か ら、建物を河川の両側に「八の字」型に配置すること により、風向きにより河風の選択的導入が可能になる ことが示されている（図5）。

この例のように、河風の広がり方は、街路の方向と 風向との関係に非常に敏感に影響される。図 7 は隅田 川の永代橋付近での実測結果であるが、測定された街 路（永代通り）の僅かの傾きで、河風の広がりは完全 に西側のみに限定されている7)。
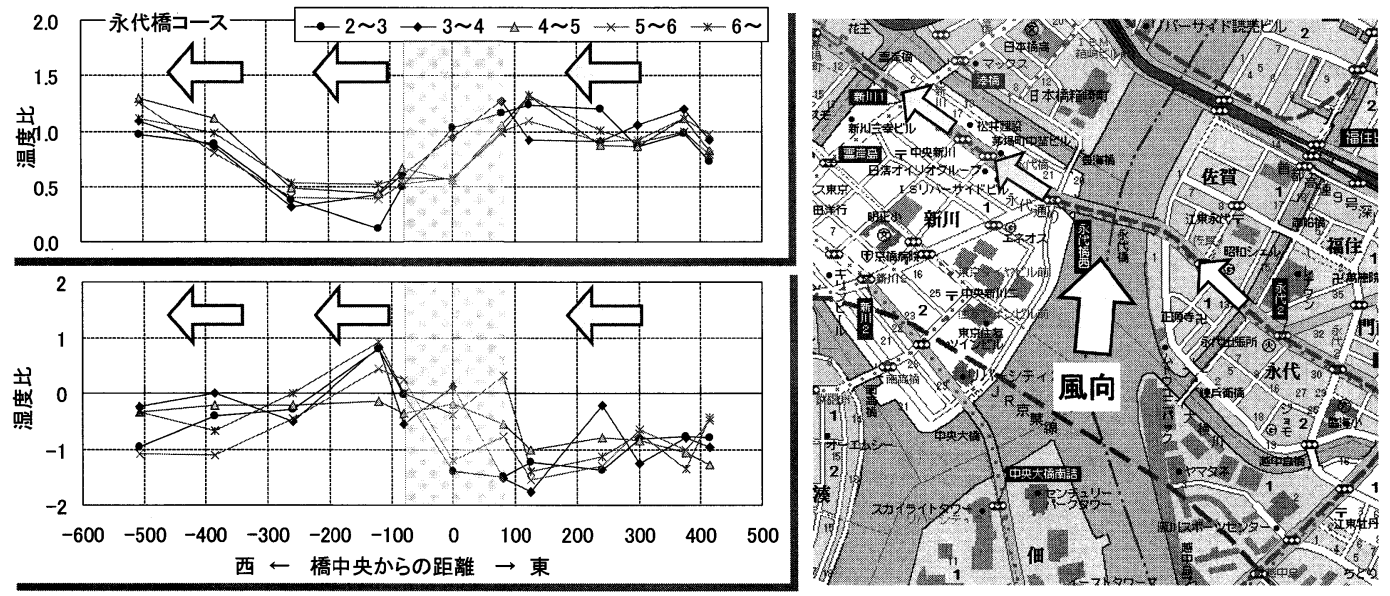

図7. 河川周辺の気温と湿度の実測例 (隅田川·永代橋周辺 $)^{(7)}$ 
これまで紹介した例は、いずれも河幅が $200 \mathrm{~m}$ 程度 の場合であるが、50m以下の河幅では、むしろ周辺市 街地からの暖気の流入が勝り、周辺市街地を冷やすほ どの効果はあまり期待できなくなるようである。ただ し、中小河川においても、河川周辺の中高層建物が上 空の海風を地表付近に取り込む効果により、結果的に 相対的に低温で、なおかつ風が吹き抜ける状況となっ ているケースは多々ある。このようなケースでは、河 口から連続していなくても、途中から、河道がいわゆ る「風の道」を形成していることになる。

図8は、目黒川での実測例である。上空風が河道方 向と一致する東よりの風の場合には、河口から上流ま で連続した風の道が形成されており、気温も河口から 内陸に向かって単調に昇温する分布となっている。

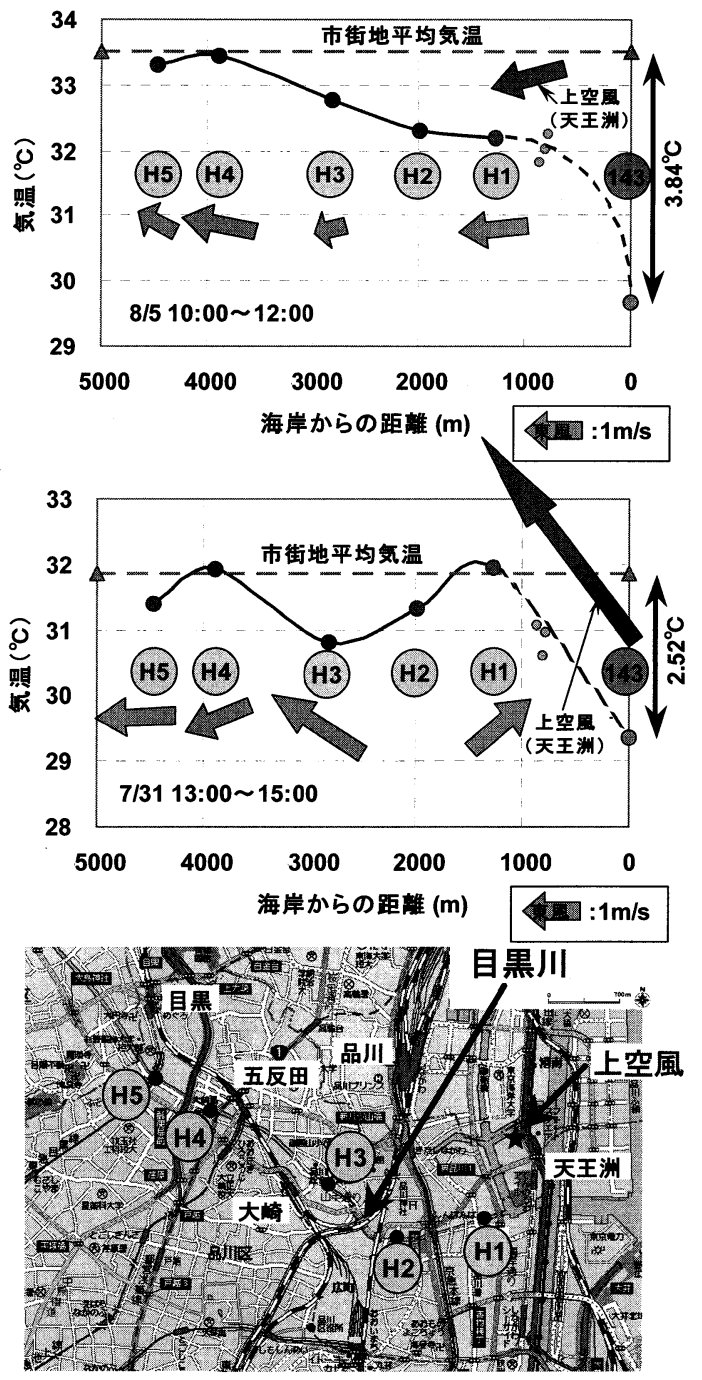

図 8. 目黒川治いの風と気温分布（東北東風時と南東風時）
一方、上空風が南東風時には、河口付近では海に向か って風が吹き、河川沿いに高層住宅が建ち並ぶ大崎付 近 (H3) より上流域では内陸に向かって連続した風の 道を形成している。このように、必ずしも河口から連 続しなくとも、河川沿いの建物による上空風の取り込 みにより、河川の途中から風の道が形成される場合が ある。上空の風は地表面近くに比べ相対的に低温であ るため、上空風の吹き降ろしに伴い、図 2 の街路空間 と同じように地上付近の気温も低下する。

以上のように、河川を利用した風の道では、河道の 方向と上空風向との関係、および河川沿いの建物配列 の状況が、現象を左右する鍵となっている。

\section{4. 市街地における海風の面的利用}

海風自体の厚さは数百 $\mathrm{m}$ にぶため、中高層の建物 を適切に配置することにより、河道部分に限らず、市 街地において面的に上空の海風を利用する可能性も指 摘できる。

（1）グロス建ぺい率と風速比の関係

近年、街区の風通しそのものを対象とした風洞実験 も行われ、興味深い結果が得られている 8)。図9は、 実在する様々な街区の市街地模型を対象に、平均的な 風速を評価した結果で、グロス建ぺい率の増加ととも に街区の風通しが悪化するという明確な関係が示され ている。また、同じグロス建ぺい率でも、低層住宅地 よりも中高層の集合住宅の場合の方がはるかに風通し が良くなるという結果になっている。

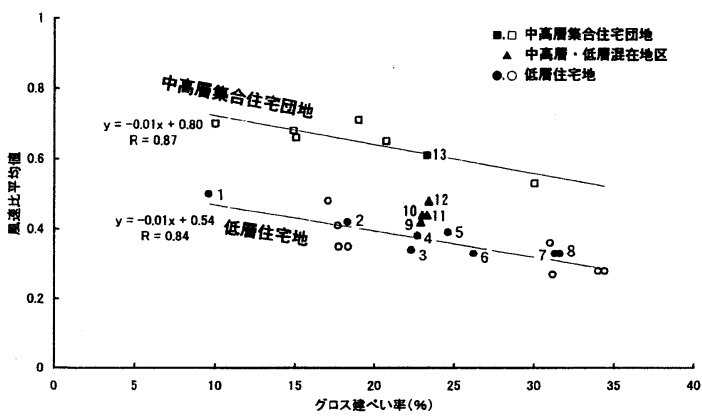

図9. グロス建ぺい率と風速比平均値の関係

（2）輸送速度による風通しの間接評価

市街地における風速分布は、非常に局所性が強いた め、以上のようなエリア平均の風通しを評価するには、 多点での風速計測が必要となり多大な労力を要する。 一方、ヒートアイランドのモデル化を念頭に、建物配 列による地表面の輸送速度の変化を検討した風洞実験 の事例があり、その結果は、間接的ではあるが、街区 

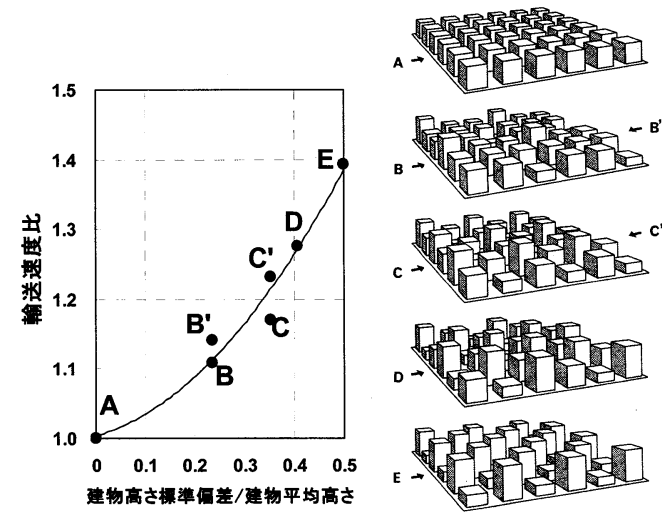
図 10. 建物高さのパラツキによるエリア平均地表
面輸送係数の変化(風洞実験-塩分濃度法)

の風通しを空間平均として評価しているとみなすこと ができる。図 10 は、結果の一例で、容積率一定の条 件下における建物高さのバラツキの影響を検討したも のである 9)。建物高さが全て等しいケースに比べ、最 大で約 $40 \%$ も輸送速度が増大している。

建物を建てることは地表面の摩擦（粗度）を増やす ことになり、地表付近の風速を弱めるのでヒートアイ ランド現象にはマイナスにしかならないという意見が ある。しかしながら、都市全体の放熱効率を考えた場 合、真平らな都市は必ずしも最適解ではない。そのこ とは、熱交換器をイメージすれば容易に理解できるは ずである。現在、行政では、卓越風向に対する建物の 見付面積をできるだけ小さくするよう指導が行われつ
つる。建築物総合環境性能評価システム CASBEE-HI でも、その方が評価は高くなる仕組みに なっている。敷地単位の評価システムとして、その主 旨は理解できるが、この点に関しては検討の余地が残 されているのかもしれない。

\section{5. 夜間冷気流の利用}

緑地からの泠気のにじみ出し現象は、丸田が 1972 年にその存在を指摘したのが最初である 10)が、非常に 風速が弱いため、その動きを直接とらえた研究は皆無 であった。最近になって、超音波風速温度計を多点に 配した詳細な観測から、その存在が明確にとらえられ た（図 11）11）。流出流速は $0.1 〜 0.3 \mathrm{~m} / \mathrm{s}$ と非常に弱い が、その泠気層の厚さは、新宿御苑の場合平均で約 9 $\mathrm{m}$ 程度であることが分かっている。流出した冷気は、 ほとんど変質することなく市街地に流れだし、80〜 $100 \mathrm{~m}$ 程度の位置まで達している（図 12）。先端部でも 冷気の厚さは $6 \mathrm{~m}$ 以上あり、2 階建ての戸建住宅を充 分覆える厚さである。

このようなにじみ出し現象が出現するのは、晴天か つ静穏な夜間に限られる。流出寸る冷気は主に御苑内 の芝生面で放射冷却によって地表付近に生成されてお り、苑内の窪地を埋め尽くし、溢れるようにして周囲 の市街地に流出する。冷気が止まる位置は、御苑の北 側では主要道路の位置と一致しており、交通量の多い 広幅員街路は越えられないと考えられる。一方南側の
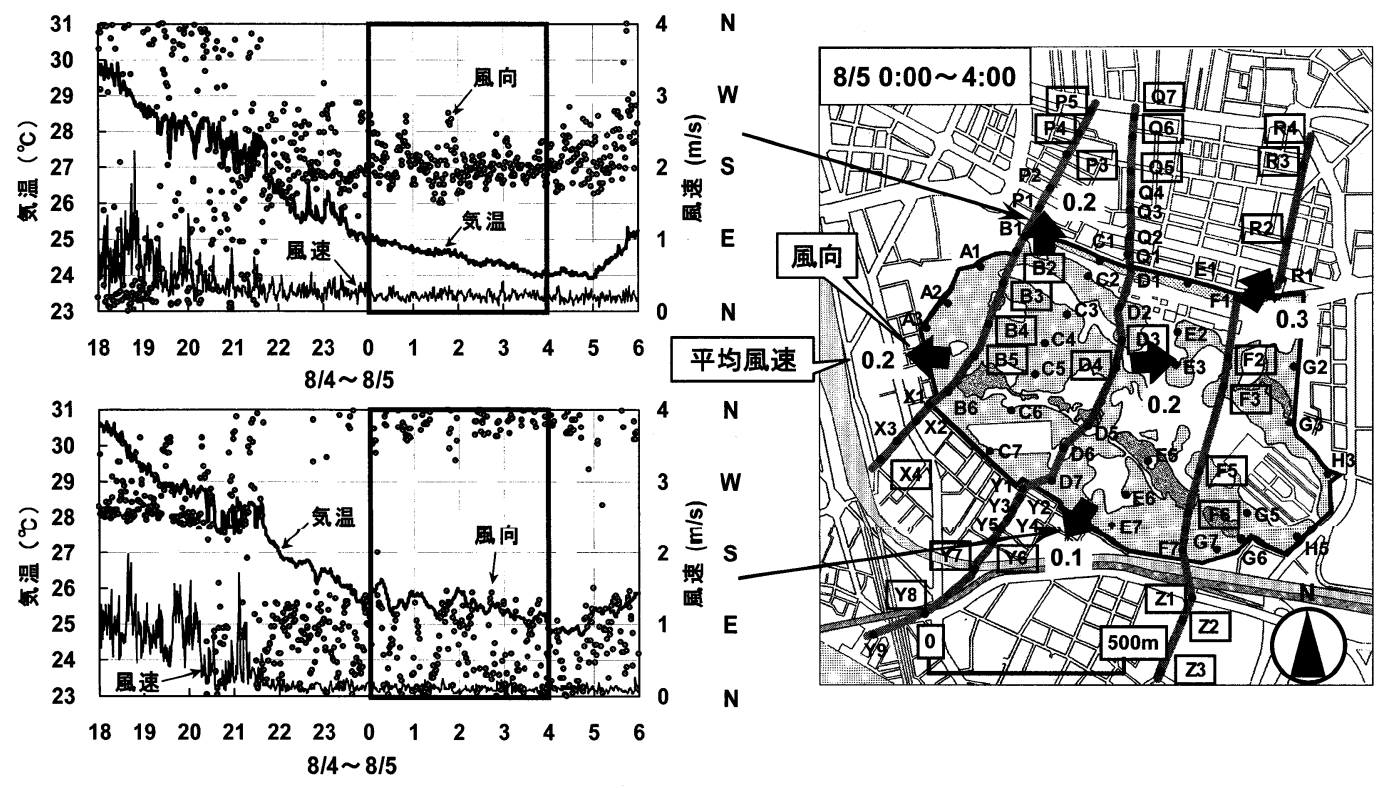

図 11. 超音波風速温度計で捉えられた「冷気のにじみ出し現象」一新宿御苑での実測例一（11） 


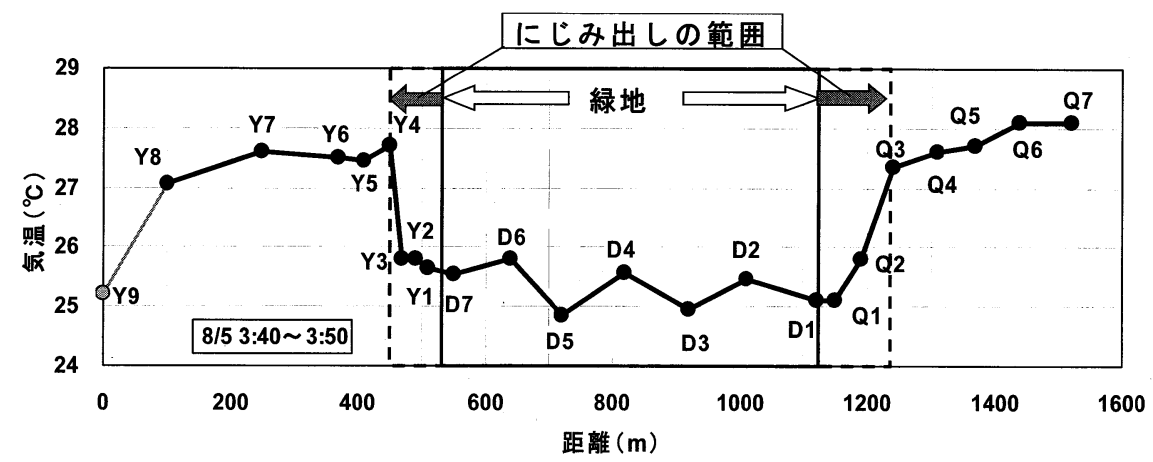

図 12.「冷気のにじみ出し現象」出現時の御苑とその周辺の気温分布(地点番号は図 11 参照)(11)

位置は目立った特長がなく、今のところ原因が特定さ れていない。冷気流はいわゆる重力流の形で流下して いくので、供給源となる緑地が周囲よりわずかでも高 い地形となっていると、にじみ出しが促進される可能 性がある。また、ドイツの事例と同様、流下方向を妨 げないような建物配置を考えるのが得策であろう。

\section{6. まとめ一風の道を活かした街づくりの指針}

（1）風の道に関しては緑や水面が連続する場所のみ に注目するのではなく、都市全体の風通しをよくする といら視点から都市のあり方を考えていくべきである。

（2）日中の海風利用に関しては、夜間冷気流とは異 なり、その厚さや規模も大きいことに留意し、平面的 なオープンスペースの連続のみに拘らず、3次元的な 導入の土夫も考えるべきである。

（3）風通しの促進は、強風害の発生と表裏一体の関 係となるため、季節風への対処も含め、季節に応じた 適風環境の創造を目指すことが必要である。

（4）河川を利用した風の道では、周辺市街地の建物 配置を工夫するとともに、市街地からの暖気の流入に よる変質を極力抑えるため、河岸域が高温化しないよ うな工夫が望まれる。

（5）大規模緑地や周辺山地斜面からの夜間冷気の利 用に関しては、海風利用とは異なり厚さ数 $\mathrm{m}$ 規模け接 地気層に限られるため、地形に配慮するとともに、流 下方向を妨げない建物配置の工夫が有効と思われる。

（6）夜間冷気の生成に関しては、生成域の人工被覆 化や天空の遮蔽を避け、放射冷却が促進される環境を 創造し維持することが肝要である。

\section{参考文献}

（1）清田誠良・成田健一・他: 街路空間における風通し と熱環境に関する実測, 日本建築学会中国・九州支
部研究報告, 10, 145-148（1996）

(2) Fukuoka Y., Narita K. and Matsuura K. : Urban climate and air quality of Hiroshima City. (1st Report). 地理科学, 32，24-32（1979）

(3) 村川三郎 - 関根 毅 - 成田健一・西名大作 ・千田勝 也 : 都市内河川が周辺の温熱環境に及ぼす効果に関 する研究(続報)，日本建築学会計画系論文集， 415 , 9-19 (1990)

（4）成田健一:都市内河川の微気象的影響範囲に及ぼす 周辺建物配列の影響に関する風洞実験, 日本建築学 会計画系論文集，442，27-35 (1992)

（5）日本建築学会編: 都市環境のクリマアトラス, ぎょ うせい (1990)

(6) Oke, T.R. : Boundary Layer Climate (2nd Ed.) Methuen, New York. (1987)

（7）成田健一・植村明子・三坂育正 : 都市気候に及ぼす 河川水の熱的影響に関する実測研究，日本建築学会 計画系論文集, 545, 71-78 (2001)

（8）久保田徹 -三浦昌生・富永禎秀・持田 灯 : 実在す る $270 \mathrm{~m}$ 平方の住宅地における地域的な風通しに関 する風洞実験一建物群の配置・集合形態が地域的な 風通しに及ぼす影響 その 1 , 日本建築学会計画系 論文集，529，109-106（2000）

(9) 成田健一・関恨 毅・徳岡利一: 市街地の蒸発量に 及ぼす建物周辺気流の影響に関する実験的研究（続 報), 日本建築学会計画系論文報告集, $366,1-11$ (1986)

(10)丸田頼一 : 公園緑地の都市自然環境におよぼす影 響，都市計画，69.70，49-77（1972）

(11)成田健一 ・三上岳彦・菅原広史・本條 毅・木村 圭司・桑田直也 : 新宿御苑におけるクールアイラン ドと冷気のにじみ出し現象, 地理学評論, 77(6), 403-420 (2004) 